\title{
A Cross Sectional Study to Assess the Prevalence of Pancreatic Exocrine Insufficiency among Diabetes Mellitus Patients in Turkey
}

\author{
Kadir Demir ${ }^{1, *}$, Cetin Karaca ${ }^{1}$, Emel Ahishali ${ }^{2}$, Metban Mastanzade ${ }^{3}$, Selda Celik ${ }^{4}$, Nurdan Gul $^{4}$, Fulya Turker ${ }^{4}$, Filiz Akyuz ${ }^{1}$, Fatih \\ Besisik $^{1}$, and Kubilay Karsidag ${ }^{4}$ \\ ${ }^{1}$ Gastroenterology Department, Istanbul University Istanbul Medical School, Istanbul, Turkey \\ ${ }^{2}$ Gastroenterology Department, Dr. Lutfi Kirdar Kartal Training and Research Hospital, Istanbul, Turkey \\ ${ }^{3}$ Internal Medicine Department, Istanbul University Istanbul Medical School, Istanbul, Turkey \\ ${ }^{4}$ Endocrinology Department, Istanbul University Istanbul Medical School, Istanbul, Turkey
}

*Correspondence to: Prof. Kadir Demir, Gastroenterology Department, Istanbul University Istanbul Medical School, 34093 Fatih-Capa Istanbul, Turkey, Tel: +90 (212) 41420 20/32117; E-mail: kadirdmr@yahoo.com

Received: November 08, 2017; Accepted: November 16, 2017; Published: November 28, 2017;

\begin{abstract}
Background/Objectives: Pancreatic exocrine insufficiency (PEI) is a common clinical entity in patients with diabetes mellitus (DM). The aim of the present study was to define the prevalence and demographic and clinical characteristics of PEI in patients with DM in Turkey.

Methods: Totally 216 patients diagnosed with DM at least five years ago or more were recruited and evaluated for clinical characteristics and fecal elastase-1 (FE-1) concentrations from stool samples by enzyme-linked immunosorbent assay for the presence of PEI. No additional therapeutic approach or follow-up visits were conducted.

Results: The mean age of the patients was $53.8 \pm 16.6$ years (18.5-85.7 years) and $58.8 \%(n=127)$ of the patients were female. Of the patients, $32.4 \%$ had Type 1 DM and $67.6 \%$ had Type 2 DM. Totally, 31 (14.3\%) patients had PEI. Mild-to-moderate PEI was observed in $12.0 \%$ of the patients and severe PEI was observed in $2.3 \%$ of the patients. The rates of PEI were $15.7 \%$ and $13.7 \%$ among Type 1 and Type 2 DM patients, respectively. FE-1 level was not correlated with DM duration and levels of ALP, amylase, HbA1c, and lipase in Type 1 and Type 2 DM patients and entire study population. There was a positive correlation between FE- 1 and C-peptide levels in Type 2 DM patients $(\mathrm{p}=0.047$, rho $=0.168)$.
\end{abstract}

Conclusions: PEI was not a rare condition both in patients with Type 1 and Type 2 DM. As the clinical presentation of diabetic patient is inconclusive regarding exocrine pancreas functions, PEI should be notably taken into consideration in daily practice.

Key words: diabetes mellitus; fecal elastase-1; pancreatic exocrine insufficiency

\section{Introduction}

Exocrine and endocrine functions of pancreas are associated closely in terms of anatomical and physiological patterns [1-3]. Pathological conditions of the exocrine tissue can cause impairment of the endocrine functions and vice versa $[1,2]$. Some conditions or diseases such as acute and chronic pancreatitis, pancreatic surgery, hemochromatosis, cystic fibrosis, and pancreatic cancer may cause diabetes mellitus (DM) [4]. Although the older studies revealed that, these diseases were believed to cause DM only in $0.5 \%-1.2 \%$, a recent review of the currently available studies finds that this ratio is approximately $5 \%-10 \%$ [5]. The impairment of exocrine function and pancreas morphology is frequently seen in diabetic patients and the reduced exocrine function has been reported in $43 \%-80 \%$ of the Type 1 DM in the earlier studies [6-9]. Similar exocrine insufficiency has been shown in Type $2 \mathrm{DM}$, whereas some studies have suggested normal exocrine function in those patients $[6,7,10]$. In 2000, Hardt et al. [1] reported that reduced fecal elastase-1 (FE-1) concentrations were found in $56.7 \%$ of Type 1 patients, $35 \%$ of Type 2 patients, and
$18.1 \%$ of the controls and that elastase- 1 concentrations were not correlated with alcohol consumption, diabetes duration or diabetes therapy. They also concluded that diabetes secondary to exocrine disease could be much more frequent than that was believed so far. In the following years, exocrine insufficiency in Type 2 DM patients has been studied in many studies and the exocrine insufficiency prevalence has been reported between $23 \%$ and $36 \%$ [11-14].

In their review, Hardt et al. [15] reported the possible mechanisms explaining pancreatic damage in patients with DM, which were insulin as a trophic factor for exocrine tissue, changes in secretion/ action of other islet hormones, autoimmunity, and diabetes mellitus as a consequence of underlying pancreatic diseases. Based on these results, the American Diabetes Association defined diseases of the exocrine pancreas as other specific types of diabetes (some authors prefer to identify this entity as Type $3 c$ diabetes) $[4,5,16]$.

In a recently published study, Ewald et al. [17] described practical criteria based on the American Diabetes Association definition for 
Type 3c DM, which were pancreatic exocrine insufficiency (PEI; a FE-1level of $<200 \mu \mathrm{g} / \mathrm{g}$ ), presence of pathologic imaging results, and absence of diabetes-associated antibodies. In that particular study, among 1868 patients, $172(9.2 \%)$ patients could be classified as Type 3 c DM and only $51.2 \%$ (88/172) were initially classified correctly. They concluded that Type 3c DM appeared to be more common than that was generally believed and it was misdiagnosed commonly [17].

Exocrine insufficiency is common in DM patients and it might be explained as a complication of diabetes mellitus. Apparently, some patients with decreased exocrine function have Type $3 \mathrm{c}$ DM and are misdiagnosed as Type 2 or Type $1 \mathrm{DM}$ and it is more likely that Type $3 \mathrm{c} \mathrm{DM}$ is much more frequent than previously believed [18]. There are only few data about PEI in DM patients in Turkey. The primary objective of the present study was to assess the prevalence of PEI among DM patients in Turkey. The secondary objectives were to assess the prevalence of PEI among Type 1 and Type 2 DM sub-groups, to evaluate demographics and medical characteristics of the patients with PEI, and to evaluate the presence of gastrointestinal symptoms among patients with PEI.

\section{Methods}

This was a cross sectional non-interventional study which was conducted in Istanbul University Faculty of Medicine from September 2013 through February 2014 and included patients admitting to the Gastroenterology or Endocrinology Outpatient Clinic with or without symptomatic gastrointestinal problems. The study was approved by local and central ethical committees. Patients who were aged $\geq 18$ years old, previously diagnosed with DM (Type 1 or Type 2) at least 5 years ago or more and treated before enrolment, had absolute insulin deficiency and were diagnosed as Type $1 \mathrm{DM}$, and those who met at least one criteria of the Society of Endocrinology and Metabolism of Turkey on DM [19] were included. These criteria included having a blood glucose level $\geq 126 \mathrm{mg} / \mathrm{dL}$ after 8 hours of fasting, having a $2^{\text {nd }}$ hour plasma glucose level $\geq 200 \mathrm{mg} / \mathrm{dL}$ after oral glucose tolerance test with $75 \mathrm{~g}$ glucose, having DM symptoms and spontaneous plasma glucose level of $\geq 200 \mathrm{mg} / \mathrm{dL}$, and having glycated hemoglobin (HbAlc) level of $\geq 6.5 \%$ with standardized measurement technique. Patients who were pregnant or on breast feeding or had insufficient medical records were excluded. Written informed consents of the patients were obtained before the study.

All enrolled patients were evaluated only once during the study period (24 weeks). Demographic parameters and laboratory tests including the measurements of HbA1c, C-peptide, amylase, lipase, aspartate aminotransferase (AST), alanine aminotransferase (ALT), gamma-glutamyl transferase (GGT), alkaline phosphatase (ALP), calcium, phosphorous, and vitamin D levels were recorded. FE1 concentrations were measured for the presence of PEI from the stool samples by enzyme-linked immunosorbent assay based on monoclonal human specific antibodies, which is widely used as a diagnostic parameter of PEI [20,21]. PEI is classified by FE-1 level as normal exocrine function (a FE-1level of $\geq 200 \mu \mathrm{g} / \mathrm{g}$ stool), mild-tomoderate PEI (a FE-1 level of $\geq 100$ but $<200 \mu \mathrm{g} / \mathrm{g}$ stool), and severe PEI (a FE-1 level of $<100 \mu \mathrm{g} / \mathrm{g}$ stool) [22].

\section{Statistical analysis}

Descriptive statistics were expressed as number, percentage, and $95 \%$ confidence interval for categorical variables and as mean, standard deviation, median, inter-quartile range, minimum, maximum, and percentiles for continuous variables. Sub-groups were compared using Chi-square or Fisher's exact or Mantel-Haenszel test for categorical variables, using analysis of variance and/or Student test for normally distributed continuous variables and Kruskal-Wallis and/or MannWhitney $\mathrm{U}$ test for non-normally distributed variables. Correlation between PEI and other parameters was evaluated by univariate tests (Chi-square or Fisher's exact test for categorical variables and Student $\mathrm{T}$ test or Mann-Whitney $\mathrm{U}$ test for continuous variables) and by multivariate tests (logistic regression models).

Raw prevalence was calculated by number, percentage, and $95 \%$ confidence interval using Wilson methodology [23]. Prevalence was adjusted for age and gender according to the results of annual census of Turkey published by Turkish Statistical Institute [24]. Prevalence was also adjusted according to the results of the TURDEP II study [25].

\section{Results}

Among the patients $(\mathrm{n}=216)$ included in the study, 58.8\% $(\mathrm{n}=$ 127) were female. The mean age of the patients was $53.8 \pm 16.6$ years (18.5-85.7 years). The rates of patients who had a history of Type 1 and Type 2 DM were $32.4 \%(n=70)$ and $67.6 \%(n=146)$, respectively. The duration of diabetes in type 1 and type $2 \mathrm{DM}$ patients were $16.7 \pm 9.1$ years (5.0-43.6 years) and $14.8 \pm 6.2$ years (5.5-37.5 years), respectively.

The most frequent DM complication was neuropathy (25.0\%) in the entire group, retinopathy (21.4\%) in the patients with Type $1 \mathrm{DM}$, and cardiac diseases (22.6\%) in the patients with Type 2 DM. Of the patients, $42.1 \%$ had at least one DM complication. All patients with Type $1 \mathrm{DM}$ were on insulin therapy, whereas $56.2 \%$ of Type 2 DM patients were on insulin therapy. The characteristics of the patients with Type 1 and Type $2 \mathrm{DM}$ and the entire study population are presented in Table 1.

Table 1. Baseline characteristics of the patients.

\begin{tabular}{|c|c|c|c|}
\hline & $\begin{array}{l}\text { Type } 1 \text { DM } \\
(n=70)\end{array}$ & $\begin{array}{c}\text { Type 2 DM } \\
(n=146)\end{array}$ & $\begin{array}{c}\text { Entire Group } \\
\quad(n=216)\end{array}$ \\
\hline Age & $\begin{array}{c}34 \pm 11.3 \\
(18.5-69.4)\end{array}$ & $\begin{array}{c}63.2 \pm 8.3 \\
(44.7-85.7)\end{array}$ & $\begin{array}{l}53.8 \pm 16.6 \\
(18.5-85.7)\end{array}$ \\
\hline BMI $\left(\mathrm{kg} / \mathrm{m}^{2}\right)$ & $\begin{array}{c}24.3 \pm 3.9 \\
(16.8-35.7)\end{array}$ & $\begin{array}{c}30.0 \pm 4.8 \\
(20.1-44.1)\end{array}$ & $\begin{array}{c}28.1 \pm 5.3 \\
(16.8-44.1)\end{array}$ \\
\hline DM duration & $\begin{array}{l}16.7 \pm 9.1 \\
(5.0-43.6)\end{array}$ & $\begin{array}{l}14.8 \pm 6.2 \\
(5.5-37.5)\end{array}$ & $\begin{array}{l}15.4 \pm 7.3 \\
(5.0-43.6)\end{array}$ \\
\hline \multicolumn{4}{|l|}{ Gender } \\
\hline Female & $43(61.4)$ & $84(57.5)$ & $127(58.8)$ \\
\hline Male & $27(38.6)$ & $62(42.5)$ & $89(41.2)$ \\
\hline \multicolumn{4}{|l|}{ DM complication } \\
\hline Neuropathy & $10(14.3)$ & $44(30.1)$ & $54(25.0)$ \\
\hline Retinopathy & $15(21.4)$ & $30(20.5)$ & $45(20.8)$ \\
\hline Cardiac disease & $3(4.3)$ & $33(22.6)$ & $36(16.7)$ \\
\hline
\end{tabular}




\begin{tabular}{|c|c|c|c|}
\hline Nephropathy & $4(5.7)$ & $7(4.8)$ & $11(5.1)$ \\
\hline Diabetic foot & $0(0.0)$ & $1(0.7)$ & $1(0.5)$ \\
\hline Cerebrovascular disease & $0(0.0)$ & $1(0.7)$ & $1(0.5)$ \\
\hline \multicolumn{4}{|l|}{ DM treatment } \\
\hline Insulin & $70(100.0)$ & $82(56.2)$ & $152(70.4)$ \\
\hline Training & $67(95.7)$ & $112(76.7)$ & $179(82.9)$ \\
\hline Life style change & $47(67.1)$ & $93(63.7)$ & $140(64.8)$ \\
\hline Diet & $48(68.6)$ & $92(63.0)$ & $140(64.8)$ \\
\hline Oral anti-diabetic & $4(5.7)$ & $131(89.7)$ & $135(62.5)$ \\
\hline Physical exercise & $36(51.4)$ & $63(43.2)$ & $99(45.8)$ \\
\hline \multicolumn{4}{|l|}{ Gastrointestinal symptoms } \\
\hline At least 1 & $11(15.7)$ & $14(9.6)$ & $25(11.6)$ \\
\hline None & $59(84.3)$ & $132(90.4)$ & $191(88.4)$ \\
\hline \multicolumn{4}{|c|}{$\begin{array}{l}\text { Data are presented as mean } \pm \text { standard deviation (minimum-maximum) or number } \\
(\%) \text {, where appropriate. }\end{array}$} \\
\hline
\end{tabular}

Totally, 31 (14.3\%) patients had PEI in the entire study population. Mild-to-moderate PEI was observed in $12.0 \%$ of the patients and severe PEI was observed in $2.3 \%$ of the patients (Table 2 ).
Table 2. Pancreatic exocrine insufficiency in the study population.

\begin{tabular}{|l|c|c|c|}
\hline & $\begin{array}{c}\text { Type 1 DM } \\
(\mathbf{n}=\mathbf{7 0})\end{array}$ & $\begin{array}{c}\text { Type 2 DM } \\
(\mathbf{n}=\mathbf{1 4 6})\end{array}$ & $\begin{array}{c}\text { Entire group } \\
(\mathbf{n}=\mathbf{2 1 6})\end{array}$ \\
\cline { 2 - 4 } & $\mathrm{n}(\%)$ & $\mathrm{n}(\%)$ & $\mathrm{n}(\%)$ \\
\hline Normal exocrine function & $59(84.3)$ & $126(86.3)$ & $185(85.7)$ \\
\hline Any PEI & $11(15.7)$ & $20(13.7)$ & $31(14.3)$ \\
\hline Mild-to-moderate PEI & $11(15.7)$ & $15(10.3)$ & $26(12.0)$ \\
\hline Severe PEI & - & $5(3.4)$ & $5(2.3)$ \\
\hline DM, Diabetes Mellitus; PEI, Pancreatic Exocrine Insufficiency
\end{tabular}

There was no significant difference between patients with or without PEI regarding the age, BMI, DM duration or insulin usage. The most frequent DM complication was neuropathy both in the patients with (35.5\%) and without (23.1\%) PEI, without a significant difference between them $(\mathrm{p}=0.145)$. Of 31 patients with PEI, the rate of having at least one DM complication was $58.1 \%(n=18)$; there was no significant difference between the patients with and without PEI regarding the presence of at least one DM complication ( $\mathrm{p}=$ 0.052). The characteristics of the patients with and without PEI and entire study population and the results of intergroup comparisons are presented in Table 3.

Table 3. Characteristics of the patients with and without pancreatic exocrine insufficiency and entire study population and intergroup comparisons.

\begin{tabular}{|c|c|c|c|c|}
\hline & $\begin{array}{l}\text { Patients with PEI } \\
\quad(n=31)\end{array}$ & $\begin{array}{l}\text { Patients without PEI } \\
\quad(\mathrm{n}=\mathbf{1 8 5})\end{array}$ & $\begin{array}{c}\text { Entire Group } \\
\quad(n=216)\end{array}$ & $\mathbf{p}$ \\
\hline Age & $\begin{array}{l}57.0 \pm 15.8 \\
(23.5-78.7)\end{array}$ & $\begin{array}{l}53.2 \pm 16.7 \\
(18.5-85.7)\end{array}$ & $\begin{array}{l}53.7 \pm 16.6 \\
(18.5-85.7)\end{array}$ & $0.230^{*}$ \\
\hline BMI $\left(\mathrm{kg} / \mathrm{m}^{2}\right)$ & $\begin{array}{l}28.4 \pm 5.4 \\
(21.5-43.6)\end{array}$ & $\begin{array}{c}28.1 \pm 5.3 \\
(16.8-44.1)\end{array}$ & $\begin{array}{c}28.1 \pm 5.3 \\
(16.8-44.1)\end{array}$ & $0.907^{*}$ \\
\hline DM duration & $\begin{array}{l}16.8 \pm 7.8 \\
(5.5-32.6)\end{array}$ & $\begin{array}{l}15.2 \pm 7.2 \\
(5.0-43.6)\end{array}$ & $\begin{array}{l}15.4 \pm 7.3 \\
(5.0-43.6)\end{array}$ & $0.345^{*}$ \\
\hline \multicolumn{5}{|l|}{ Gender } \\
\hline Female & $19(61.3)$ & $108(58.4)$ & $127(58.8)$ & \multirow{2}{*}{0.760} \\
\hline Male & $12(38.7)$ & $77(41.6)$ & $89(41.2)$ & \\
\hline \multicolumn{5}{|l|}{ DM complication } \\
\hline Neuropathy & $11(35.5)$ & $43(23.1)$ & $54(25.0)$ & 0.145 \\
\hline Retinopathy & $7(22.6)$ & $38(20.4)$ & $45(20.8)$ & 0.796 \\
\hline Cardiac disease & $6(19.4)$ & $30(16.1)$ & $36(16.7)$ & 0.664 \\
\hline Nephropathy & $2(6.5)$ & $9(4.8)$ & $11(5.1)$ & $0.661 * *$ \\
\hline Diabetic foot & $0(0.0)$ & $1(0.5)$ & $1(0.5)$ & $1.000 * *$ \\
\hline Cerebrovascular disease & $0(0.0)$ & $1(0.5)$ & $1(0.5)$ & 1.000 \\
\hline \multicolumn{5}{|l|}{ DM treatment } \\
\hline Insulin & $26(83.9)$ & $126(67.7)$ & $152(70.4)$ & 0.873 \\
\hline Oral anti-diabetic & $21(67.7)$ & $114(61.3)$ & $135(62.5)$ & 0.515 \\
\hline \multicolumn{5}{|l|}{ Gastrointestinal symptoms } \\
\hline At least 1 & $2(6.5)$ & $23(12.4)$ & $25(11.6)$ & \multirow{2}{*}{0.335} \\
\hline None & $29(93.5)$ & $162(87.6)$ & $191(88.4)$ & \\
\hline \multicolumn{5}{|c|}{$\begin{array}{l}\text { Data are presented as mean } \pm \text { standard deviation (minimum-maximum) or number (\%), where appropriate. Chi-square test was used unless otherwise stated; *Mann } \\
\text { Whitney U test; ** Fisher's exact test. } \\
\text { BMI, Body Mass Index; DM, Diabetes Mellitus; PEI, Pancreatic Exocrine Insufficiency. }\end{array}$} \\
\hline
\end{tabular}




\section{Laboratory Findings}

The entire study population, as well as Type 1 and Type 2 DM patients, was grouped according to the presence and absence of PEI. The laboratory findings of these groups and the results of comparisons are presented in Table 4. There were no significant differences regarding any laboratory parameters between the patients with and without PEI in each group, except for vitamin D level in the patients with Type $1 \mathrm{DM}(\mathrm{p}=0.010)$.

Type $2 \mathrm{DM}$ patients receiving and not receiving insulin therapy were grouped according to the presence and absence of PEI and were evaluated regarding laboratory findings. The laboratory findings of these groups and the results of comparisons are presented in Table 5. The mean amylase level was significantly higher in Type 2 DM patients not receiving insulin therapy without PEI than in those receiving insulin therapy with PEI $(p=0.009)$. The mean ALT level was significantly higher in Type $2 \mathrm{DM}$ patients receiving insulin therapy with PEI than in those not receiving insulin therapy without PEI $(\mathrm{p}=0.024)$.

To evaluate the relationship between glycemic control and PEI, patients with DM Type 1 or 2 were divided into subgroups according to having $\mathrm{HbA} 1 \mathrm{c}$ levels equal or higher than $7 \%$ and smaller than $7 \%$. There was no correlation between these subgroups and PEI status in Type 1 and Type 2 DM patients (Table 6).

Table 4. Laboratory findings of Type 1 and Type 2 diabetes mellitus patients and entire study population grouped according to the presence of pancreatic exocrine insufficiency and results of comparisons.

\begin{tabular}{|c|c|c|c|c|c|c|c|c|}
\hline & \multirow{2}{*}{$\mathbf{n}$} & \multicolumn{3}{|c|}{ Type 1 DM } & \multirow{2}{*}{$\mathbf{n}$} & \multicolumn{3}{|c|}{ Type 2 DM } \\
\hline & & With PEI & Without PEI & $\mathbf{p}$ & & With PEI & Without PEI & $\mathbf{p}$ \\
\hline $\mathrm{HbA1C}(\%)$ & 70 & $\begin{array}{c}8.5 \pm 2.0 \\
(6.3-13.8)\end{array}$ & $\begin{array}{c}8.3 \pm 1.6 \\
(5.2-13.0)\end{array}$ & 0.981 & 145 & $\begin{array}{c}7.5 \pm 1.4 \\
(6.0-11.4)\end{array}$ & $\begin{array}{c}7.7 \pm 1.3 \\
(5.3-12.7)\end{array}$ & 0.457 \\
\hline C-Peptide $(\mathrm{pmol} / \mathrm{mL})$ & 69 & $\begin{array}{l}0.10 \pm 0.22 \\
(0.01-0.74)\end{array}$ & $\begin{array}{l}0.23 \pm 0.50 \\
(0.01-2.24)\end{array}$ & 0.223 & 140 & $\begin{array}{l}2.10 \pm 1.57 \\
(0.01-6.63)\end{array}$ & $\begin{array}{l}2.48 \pm 1.30 \\
(0.01-6.25)\end{array}$ & 0.144 \\
\hline Amylase (IU/L) & 65 & $\begin{array}{l}63.6 \pm 31.7 \\
(8.7-130.0)\end{array}$ & $\begin{array}{c}65.5 \pm 31.2 \\
(19.0-205.0)\end{array}$ & 0.920 & 145 & $\begin{array}{c}68.7 \pm 36.7 \\
(9.8-20.0)\end{array}$ & $\begin{array}{l}73.2 \pm 35.5 \\
(4.8-125.0)\end{array}$ & 0.424 \\
\hline Lipase (U/L) & 65 & $\begin{array}{l}29.6 \pm 28.6 \\
(6.2-105.0)\end{array}$ & $\begin{array}{c}46.5 \pm 52.7 \\
(11.6-268.0)\end{array}$ & 0.122 & 144 & $\begin{array}{c}34.8 \pm 16.7 \\
(7.2-63.4)\end{array}$ & $\begin{array}{l}47.4 \pm 41.9 \\
(7.8-292.0)\end{array}$ & 0.244 \\
\hline $\operatorname{AST}(\mathrm{U} / \mathrm{L})$ & 70 & $\begin{array}{c}18.9 \pm 5.9 \\
(10.0-29.0)\end{array}$ & $\begin{array}{l}18.5 \pm 8.4 \\
(8.0-70.0)\end{array}$ & 0.512 & 145 & $\begin{array}{c}21.7 \pm 9.0 \\
(12.0-44.0)\end{array}$ & $\begin{array}{c}19.9 \pm 6.1 \\
(11.0-42.0)\end{array}$ & 0.638 \\
\hline ALT (U/L) & 70 & $\begin{array}{l}18.0 \pm 8.9 \\
(9.0-36.0)\end{array}$ & $\begin{array}{l}19.5 \pm 16.9 \\
(7.0-128.0)\end{array}$ & 0.859 & 145 & $\begin{array}{c}26.6 \pm 24.9 \\
(10.0-122.0)\end{array}$ & $\begin{array}{c}24.0 \pm 12.8 \\
(9.0-85.0)\end{array}$ & 0.560 \\
\hline GGT (U/L) & 69 & $\begin{array}{l}16.6 \pm 7.8 \\
(9.0-36.0)\end{array}$ & $\begin{array}{l}28.2 \pm 65.3 \\
(6.0-494.0)\end{array}$ & 0.693 & 142 & $\begin{array}{c}28.4 \pm 16.8 \\
(8.0-75.0)\end{array}$ & $\begin{array}{l}26.3 \pm 16.4 \\
(7.0-122.0)\end{array}$ & 0.571 \\
\hline Calcium (mg/dL) & 68 & $\begin{array}{l}9.4 \pm 0.3 \\
(8.9-9.7)\end{array}$ & $\begin{array}{c}9.6 \pm 0.4 \\
(8.8-10.7)\end{array}$ & 0.100 & 145 & $\begin{array}{c}9.7 \pm 0.4 \\
(8.8-10.5)\end{array}$ & $\begin{array}{c}9.8 \pm 0.5 \\
(8.3-12.0)\end{array}$ & 0.472 \\
\hline Phosphorus (mg/dL) & 68 & $\begin{array}{l}3.8 \pm 0.4 \\
(3.2-4.5)\end{array}$ & $\begin{array}{l}3.6 \pm 0.6 \\
(2.4-5.4)\end{array}$ & 0.079 & 146 & $\begin{array}{l}3.5 \pm 0.4 \\
(2.7-4.2)\end{array}$ & $\begin{array}{l}3.6 \pm 0.6 \\
(2.2-5.3)\end{array}$ & 0.749 \\
\hline Vitamin D (ng/mL) & 60 & $\begin{array}{l}19.8 \pm 8.3 \\
(9.6-31.0)\end{array}$ & $\begin{array}{l}12.8 \pm 9.0 \\
(4.0-47.9)\end{array}$ & 0.010 & 133 & $\begin{array}{c}17.4 \pm 10.0 \\
(5.1-34.5)\end{array}$ & $\begin{array}{c}17.3 \pm 10.4 \\
(5.0-62.5)\end{array}$ & 0.963 \\
\hline \multicolumn{9}{|c|}{$\begin{array}{l}\text { Data are presented as mean } \pm \text { standard deviation (minimum-maximum) or number (\%), where appropriate. } \\
\text { DM, Diabetes Mellitus; PEI, Pancreatic Exocrine Insufficiency; HbA1c, Glycated Hemoglobin; AST, Aspartate Aminotransferase; ALT, Alanine Aminotransferase; GGT } \\
\text { Gamma-Glutamyl Transferase. }\end{array}$} \\
\hline
\end{tabular}


Kadir Demir (2017) A Cross Sectional Study to Assess the Prevalence of Pancreatic Exocrine Insufficiency among Diabetes Mellitus Patients in Turkey

Table 5. Laboratory findings of Type 2 diabetes mellitus patients receiving and not receiving insulin therapy grouped according to the presence of pancreatic exocrine insufficiency and results of comparisons.

\begin{tabular}{|c|c|c|c|c|c|c|c|c|}
\hline & & Patie & iving Insulin T & & & Patie & Receiving Insu & \\
\hline & & With PEI & Without PEI & $\mathbf{p}$ & & With PEI & Without PEI & $\mathbf{p}$ \\
\hline $\mathrm{HbAlC}(\%)$ & 81 & $\begin{array}{l}7.7 \pm 1.5 \\
(6-11.4)\end{array}$ & $\begin{array}{c}8.1 \pm 1.4 \\
(5.8-12.7)\end{array}$ & 0.099 & 64 & $\begin{array}{l}7.2 \pm 1.2 \\
(6.3-9.2)\end{array}$ & $\begin{array}{c}7.2 \pm 1 \\
(5.3-9.5)\end{array}$ & 0.822 \\
\hline C-Peptide $(\mathrm{pmol} / \mathrm{mL})$ & 80 & $\begin{array}{c}1.6 \pm 1 \\
(0.01-3.9)\end{array}$ & $\begin{array}{c}2.1 \pm 1.3 \\
(0.01-5.9)\end{array}$ & 0.247 & 60 & $\begin{array}{l}4.1 \pm 1.8 \\
(2.6-6.6)\end{array}$ & $\begin{array}{c}3 \pm 1.1 \\
(0.01-6.3)\end{array}$ & 0.134 \\
\hline Amylase (IU/L) & 81 & $\begin{array}{c}74.4 \pm 41.1 \\
(9.8-193)\end{array}$ & $\begin{array}{c}71.5 \pm 42.7 \\
(20-279)\end{array}$ & 0.504 & 64 & $\begin{array}{l}51.8 \pm 5 \\
(47-57)\end{array}$ & $\begin{array}{c}75.1 \pm 25.5 \\
(4.8-145)\end{array}$ & 0.009 \\
\hline Lipase (U/L) & 82 & $\begin{array}{c}36.2 \pm 18.9 \\
(7.2-63.4)\end{array}$ & $\begin{array}{c}43.2 \pm 40.2 \\
(7.8-292)\end{array}$ & 0.905 & 62 & $\begin{array}{c}30.6 \pm 7.2 \\
(22.2-38.4)\end{array}$ & $\begin{array}{c}52.3 \pm 43.7 \\
(12.8-286)\end{array}$ & 0.057 \\
\hline AST (U/L) & 81 & $\begin{array}{c}18.9 \pm 4.8 \\
(12-28)\end{array}$ & $\begin{array}{c}19.7 \pm 5.8 \\
(11-34)\end{array}$ & 0.798 & 64 & $\begin{array}{c}29.8 \pm 13.9 \\
(14-44)\end{array}$ & $\begin{array}{c}20.1 \pm 6.6 \\
(11-42)\end{array}$ & 0.184 \\
\hline $\operatorname{ALT}(\mathrm{U} / \mathrm{L})$ & 82 & $\begin{array}{c}17.5 \pm 5.1 \\
(10-26)\end{array}$ & $\begin{array}{c}22.5 \pm 10.7 \\
(9-54)\end{array}$ & 0.560 & 63 & $\begin{array}{c}53.6 \pm 40.5 \\
(22-122)\end{array}$ & $\begin{array}{c}25.8 \pm 14.9 \\
(10-85)\end{array}$ & 0.024 \\
\hline $\mathrm{GGT}(\mathrm{U} / \mathrm{L})$ & 81 & $\begin{array}{c}24.8 \pm 12.6 \\
(8-52)\end{array}$ & $\begin{array}{c}26.4 \pm 16.5 \\
(7-122)\end{array}$ & 0.742 & 61 & $\begin{array}{c}39 \pm 24.4 \\
(11-75)\end{array}$ & $\begin{array}{c}26.2 \pm 16.5 \\
(10-86)\end{array}$ & 0.242 \\
\hline Calcium (mg/dL) & 82 & $\begin{array}{c}9.6 \pm 0.5 \\
(8.8-10.5)\end{array}$ & $\begin{array}{c}9.7 \pm 0.4 \\
(8.8-10.6)\end{array}$ & 0.478 & 63 & $\begin{array}{c}9.9 \pm 0.2 \\
(9.7-10.1)\end{array}$ & $\begin{array}{l}9.9 \pm 0.6 \\
(8.3-12)\end{array}$ & 0.711 \\
\hline Phosphorus (mg/dL) & 82 & $\begin{array}{l}3.6 \pm 0.4 \\
(2.7-4.2)\end{array}$ & $\begin{array}{l}3.6 \pm 0.6 \\
(2.2-4.7)\end{array}$ & 0.943 & 64 & $\begin{array}{c}3.3 \pm 0.4 \\
(3-3.9)\end{array}$ & $\begin{array}{l}3.5 \pm 0.6 \\
(2.3-5.3)\end{array}$ & 0.254 \\
\hline Vitamin $\mathrm{D}(\mathrm{ng} / \mathrm{mL})$ & 74 & $\begin{array}{c}18 \pm 10.9 \\
(5.1-34.5)\end{array}$ & $\begin{array}{c}14.5 \pm 7.7 \\
(5-39.3)\end{array}$ & 0.485 & 59 & $\begin{array}{l}15.9 \pm 8 \\
(8-27.1)\end{array}$ & $\begin{array}{c}20.5 \pm 12.2 \\
(5.4-62.5)\end{array}$ & 0.460 \\
\hline
\end{tabular}

Data are presented as mean \pm standard deviation (minimum-maximum) or number (\%), where appropriate.

PEI, Pancreatic Exocrine Insufficiency; HbA1c, Glycated Hemoglobin; AST, Aspartate Aminotransferase; ALT, Alanine Aminotransferase; GGT, Gamma-Glutamyl Transferase.

Table 6. Relationship of glycated hemoglobin level with pancreatic exocrine insufficiency in Type 1 and Type 2 diabetes mellitus patients and entire study population.

\begin{tabular}{|c|c|c|c|c|c|c|c|c|c|}
\hline & \multicolumn{3}{|c|}{$\begin{array}{l}\text { Type } 1 \text { DM } \\
(n=56)\end{array}$} & \multicolumn{3}{|c|}{$\begin{array}{c}\text { Type } 2 \text { DM } \\
(\mathrm{n}=98)\end{array}$} & \multicolumn{3}{|c|}{$\begin{array}{c}\text { Entire group } \\
(\mathbf{n}=154)\end{array}$} \\
\hline & HbA1c $<7.0 \%$ & $\mathrm{HbA} 1 \mathrm{c} \geq 7.0 \%$ & \multirow{2}{*}{ p } & HbA1c $<7.0 \%$ & $\mathrm{HbA} 1 \mathrm{c} \geq 7.0 \%$ & \multirow{2}{*}{$\mathbf{p}$} & HbA1c $<7.0 \%$ & HbA1c $\geq 7.0 \%$ & \multirow{2}{*}{$\mathbf{p}$} \\
\hline & n (\%) & n (\%) & & n (\%) & $\mathrm{n}(\%)$ & & $\mathrm{n}(\%)$ & $\mathrm{n}(\%)$ & \\
\hline With PEI & $2(18.2)$ & $9(81.8)$ & \multirow{2}{*}{$1.000^{*}$} & $9(45.0)$ & $11(55.0)$ & \multirow{2}{*}{0.195} & $11(35.5)$ & $20(64.5)$ & \multirow{2}{*}{0.342} \\
\hline Without PEI & $12(20.3)$ & $47(79.7)$ & & $38(30.4)$ & $87(69.6)$ & & $50(27.2)$ & $134(72.8)$ & \\
\hline
\end{tabular}

Chi-square test was used unless otherwise stated. *Fisher's exact test.

DM, Diabetes Mellitus; HbA1c, Glycated Hemoglobin; PEI, Pancreatic Exocrine Insufficiency.

Fecal elastase-1 level was not correlated with DM duration and levels of ALP, amylase, HbA1c, and lipase in Type 1 and Type 2 DM patients and entire study population. There was a positive correlation between FE-1 level and C-peptide level in Type 2 DM patients ( $\mathrm{p}=$ 0.047 , rho $=0.168)$. Univariate linear regression model revealed that amylase, lipase, and ALP levels and Type 2 DM were not significant predictors of FE-1 level. Univariate logistic regression model revealed that amylase, lipase, and ALP levels and Type 2 DM were not significant predictors of PEI.

\section{Discussion}

During the previous decades, researchers have focused on PEI in DM in many studies and evaluated the pancreatic secretion after the injection of cholecystokinin-pancreozymin and secretin in early studies [26]. The results of these studies have revealed that the prevalence rates of PEI ranges between $43 \%$ to $80 \%$ [6, 8, 9, 27]. More recently, FE-1 has become a frequently used diagnostic method in the clinical practice to detect PEI. Studies utilizing this diagnostic method have also reported high prevalence of PEI in patients with $\mathrm{DM}$, ranging between $5.4 \%-56.7 \%$ which is slightly lower than the results of previous studies $[1,12,26,28-30]$. 
The results of the present study revealed that PEI was not a rare condition among patients with DM, either Type 1 or Type 2. The overall prevalence of PEI in the study population was found to be $14.4 \%$ and almost 1 in 7 patients with DM appeared to have PEI. This result also confirmed that, in general daily practice, the awareness of Type 1 and Type $2 \mathrm{DM}$ is well-established; however, Type $3 \mathrm{cDM}$ is rarely considered [31]. This finding is also consistent with the previous studies, which have shown that this particular subtype of diabetes is more common than that is thought and generally misdiagnosed $[17,20]$.

There are some mechanisms proposed to be responsible for the impaired exocrine function in DM, including insulin deficienc [32], diabetic microangiopathy [33] high levels of circulating glucagon and its suppressive effects [34], effects of different hormones like somatostatin or pancreatic polypeptide [35] and autoimmunity against both endocrine and exocrine pancreas [36]. Regardless of the mechanism, changes in the exocrine function of the pancreas are commonly seen in many diabetic patients. In the present study population, $14.4 \%$ of the patients had PEI (15.7\% in Type $1 \mathrm{DM}$ and $13.7 \%$ in Type $2 \mathrm{DM}$ ); this was a relatively small rate when compared with the results of the previous studies. In their study populations, the rates of PEI were found as 55\% by Chey et al. [6] and 73\% by Vacca et al. [7] More recently, Hardt et al. [1] found that fecal elastase test was abnormal in $57 \%$ of patients with Type $1 \mathrm{DM}$ and $35 \%$ of patients with Type $2 \mathrm{DM}$. The results of the present study are in conflict with the previous studies with the relatively small rates, but in consistent with the recent studies. $[11,14,37]$. In a study included 544 Type 2 diabetic patients (age: $63 \pm 8$ years) and 544 age-and gender-matched controls, Rahtmann et al. [11] reported that FE-1 concentrations were significantly lower in the patients than those of the controls and that low levels of FE-1 concentrations was present in $11.9 \%$ of the patients and $3.7 \%$ of the controls. In another study conducted by Larger et al. [14] on 667 patients (195 Type 1 DM and 472 Type 2 DM patients), 23\% of the patients had an elastase 1 concentration $<200 \mu \mathrm{g} / \mathrm{g}$. Moreover, the study by Terzin et al. [37] reported lower elastase 1 concentrations in $16.8 \%$ of the patients with Type 2 DM patients $(n=101)$.

Another critical point in the present study was that the diagnostic method was based on the fecal elastase test and the impaired results suggested the deteriorated digestive pathways in these patients. In a large-scale population based study by Bytzer et al. [38] on 15, 000 adults, it was reported that gastrointestinal symptoms were observed with an increased prevalence in patients with diabetes and poor glycemic control. In the present study, at least one gastrointestinal symptom was present in $11.6 \%$ of the patients. When the diagnostic subgroups were considered, $15.7 \%$ of Type $1 \mathrm{DM}$ patients and $9.6 \%$ of Type $2 \mathrm{DM}$ patients had gastrointestinal symptoms. When the presence of gastrointestinal symptoms was compared according to the presence of PEI, there was no statistically significant difference between the groups. This finding was contradictory to the results of the previous studies by Nunes et al. [29], Icks et al. [28], and Rathmann et al. [11], which all reported that deteriorations in exocrine functions also impaired digestive functions in DM. However, this finding also supported some previous reports, which stated the controversies in the clinical presentation of PEI [26].
The duration of DM and the treatment with insulin are known as significant contributors to the changes in levels of digestive enzymes, such as amylase, in diabetes. Previous studies have shown that enzyme levels are significantly decreased in most diabetic cases with a long duration of disease and insulin treatment [39]. In the present study, there were no significant differences regarding enzyme levels between the patients with and without PEI neither in Type 1 nor in Type 2 diabetes. However, in the Type $2 \mathrm{DM}$ patients not receiving insulin therapy, serum amylase level was significantly lower in the patients with PEI than in those without PEI. This finding did not support the previous evidence about insulin usage [29]. Layer et al. [40] reported on this issue that despite the decreased enzyme levels, there were no clinical evidence of pancreatic exocrine disease in these patients; however, according to our results, PEI was present in the patients with decreased amylase levels. Nevertheless, we could not define an effect of disease duration on the presence of PEI. The patients had similar duration of diabetes in both groups with and without PEI.

Presence of obesity and increased BMI are significant factors in the prognosis of DM. In the present study population, BMI was higher in the patients with Type 2 DM but not found to be differed between the patients with and without PEI. This was also mentioned by the previous studies and excess body weight defined as a BMI of $>25 \mathrm{~kg} /$ $\mathrm{m} 2$ was not reported to be effective on fecal elastase levels.29 However, regardless of BMI, poor glycemic control has been associated with decreased exocrine functions of pancreas $[11,37]$.

Although some recent studies showed that PEI have been seen more frequently in the patients with poor glycemic control (HbA1c $\geq \% 7)$ than in the patients with good glycemic control (HbA1c <\%7) $[11,37]$, we did not find a correlation between PEI and glycemic control. Larger et al. had also indicated the similar results as we found [14]. According to these findings, the relationship between poor glycemic control and PEI is still contradictory and needs more studies to evaluate.

Vitamin D is a fat-soluble vitamin and its deficiency is expected more common in patients with PEI than without PEI. According to our results, the prevalence of vitamin D deficiency does not differ between diabetics with PEI and without PEI. It may be the reason of high prevalence of vitamin D deficiency in Turkey [41].

In conclusion, this is one of the very few studies about the prevalence and characteristics of PEI in patients with diabetes in Turkey. Although the prevalence rate of PEI in DM in our study was not found as high as in the previous studies, PEI was not a rare condition both in Type 1 and Type $2 \mathrm{DM}$; and these patient population has to be considered as Type 3c DM. Generally, the demographic and clinical characteristics were similar in the patients with and without PEI and the clinical presentation was inconclusive in these patients regarding exocrine pancreas functions. Although these findings should be supported by further, large-scale, prospective, randomized and controlled studies, our results contribute to the current evidence as new data from a less-studied population. 


\section{Acknowledgements}

The authors declare that there is no conflict of interest. This study was financially supported by Abbott Laboratories Turkey.

\section{References}

1. Hardt PD, Krauss A, Bretz L, Porsch-Ozcürümez M, Schnell-Kretschmer H, et al. (2000) Pancreatic exocrine function in patients with type 1 and type 2 diabetes mellitus. Acta Diabetol 37: 105-110. [Crossref]

2. Keller J, Layer P (2004) Acinar-Islet Interactions: Pancreatic Exocrine Insufficiency in Diabetes Mellitus. In: Pancreatic Disease: basic science and clinical management, Johnson CD, Imrie CW (eds) Springer-Verlag London; pp. 267-278.

3. Nyman LR, Wells KS, Head WS, McCaughey M, Ford E, et al. (2008) Realtime, multidimensional in vivo imaging used to investigate blood flow in mouse pancreatic islets. J Clin Invest 118: 3790-3797. [Crossref]

4. American Diabetes Association. Diagnosis and Classification of Diabetes Mellitus. Diabetes Care 2013; 36(S1): S67-S74.

5. Ewald N, Bretzel RG (2013) Diabetes mellitus secondary to pancreatic diseases (Type 3c)--are we neglecting an important disease? Eur J Intern Med 24: 203-206. [Crossref]

6. Chey WY, Shay H, Shuman CR (1963) External pancreatic secretion in diabetes mellitus. Ann Intern Med 59: 812-821. [Crossref]

7. Vacca JB, Henke WJ, Knight WA Jr (1964) The exocrine pancreas in diabetes mellitus. Ann Intern Med 61: 242-247. [Crossref]

8. Frier BM, Saunders JH, Wormsley KG, Bouchier IA (1976) Exocrine pancreatic function in juvenile-onset diabetes mellitus. Gut 17: 685-691. [Crossref]

9. Lankisch PG, Manthey G, Otto J, Koop H, Talaulicar M, et al. (1982) Exocrine pancreatic function in insulin-dependent diabetes mellitus. Digestion 25: 211-216. [Crossref]

10. Gröger G, Layer P (1995) Exocrine pancreatic function in diabetes mellitus. Eur J Gastroenterol Hepatol 7: 740-746. [Crossref]

11. Rathmann W, Haastert B, Icks A, Giani G, Hennings S, et al. (2001) Low faecal elastase 1 concentrations in type 2 diabetes mellitus. Scand J Gastroenterol 36: 1056-1061. [Crossref]

12. Hardt PD, Hauenschild A, Nalop J, Marzeion AM, Jaeger C, Teichmann J, et al. (2003) High prevalence of exocrine pancreatic insufficiency in diabetes mellitus. A multicenter study screening fecal elastase 1 concentrations in 1,021 diabetic patients. Pancreatology 3: 395-402.

13. Cavalot F, Bonomo K, Perna P, Bacillo E, Salacone P, Gallo M, et al. (2004) Pancreatic elastase-1 in stools, a marker of exocrine pancreas function, correlates with both residual beta-cell secretion and metabolic control in type 1 diabetic subjects. Diabetes Care 27: 2052-2054.

14. Larger E, Philippe MF, Barbot-Trystram L, Radu A, Rotariu M, et al. (2012) Pancreatic exocrine function in patients with diabetes. Diabet Med 29: 1047-1054. [Crossref]

15. Hardt PD, Ewald N (2011) Exocrine pancreatic insufficiency in diabetes mellitus: a complication of diabetic neuropathy or a different type of diabetes? Exp Diabetes Res 2011: 761950. [Crossref]

16. Andersen DK (2012) The practical importance of recognizing pancreatogenic or type 3c diabetes. Diabetes Metab Res Rev 28: 326-328. [Crossref]

17. Ewald N, Kaufmann C, Raspe A, Kloer HU, Bretzel RG, et al. (2012) Prevalence of diabetes mellitus secondary to pancreatic diseases (type 3c). Diabetes Metab Res Rev 28: 338-342. [Crossref]

18. Ewald N, Raspe A, Kaufmann C, Bretzel RG, Kloer HU, Hardt PD (2009) Determinants of Exocrine Pancreatic Function as Measured by Fecal Elastase-1 Concentrations (FEC) in Patients with Diabetes mellitus. Eur J Med Res 14: 118-22.

19. Satman I, Imamoglu S, Yilmaz C, Akalin S, Salman S (2013) TEMD Diabetes Mellitus Çalisma ve Egitim Grubu. Türkiye Endokrinoloji ve Metabolizma Dernegi Diabetes Mellitus ve Komplikasyonlarinin Tani, Tedavi ve Izlem Kilavuzu

20. Hardt PD, Brendel MD, Kloer HU, Bretzel RG (2008) Is pancreatic diabetes (type $3 \mathrm{c}$ diabetes) underdiagnosed and misdiagnosed? Diabetes Care 31 Suppl 2: S165169. [Crossref]

21. Lüth S, Teyssen S, Forssmann K, Kölbel C, Krummenauer F, et al. (2001) Fecal elastase-1 determination: 'gold standard' of indirect pancreatic function tests? Scand J Gastroenterol 36: 1092-1099. [Crossref]

22. Domínguez Muñoz JE1 (2010) Diagnosis of chronic pancreatitis: Functional testing. Best Pract Res Clin Gastroenterol 24: 233-241. [Crossref]

23. Newcombe RG. Two-sided confidence intervals for the single proportion: comparison of seven methods. Stat Med 1998; 17: 857-72.
24. Turkish Statistical Institute. Address Based Population Registration System (ABPRS) Database. Available from: http: //rapory.tuik.gov.tr/13-05-2015-11: 33: 16-17441876598127570371714880534.html. Access Date: May 13, 2015.

25. Satman I; TURDEP-II Study Group; TURDEP II Sonuçlari (2011). Available from: http://www.turkendokrin.org/files/file/TURDEP_II_2011.pdf. Access Date: May 13, 2015. [Report in Turkish]

26. Vujasinovic M, Zaletel J, Tepes B, Popic B, Makuc J, Epsek Lenart M, et al. Low prevalence of exocrine pancreatic insufficiency in patients with diabetes mellitus. Pancreatology 2013; 3: 343-6.

27. Ewald N, Raspe A, Kaufmann C, Bretzel RG, Kloer HU, et al. (2009) Determinants of Exocrine Pancreatic Function as Measured by Fecal Elastase-1 Concentrations (FEC) in Patients with Diabetes mellitus. Eur J Med Res 14: 118-122. [Crossref]

28. Icks A, Haastert B, Giani G, Rathmann W (2001) Low fecal elastase-1 in type I diabetes mellitus. Z Gastroenterol 39: 823-830. [Crossref]

29. Nunes AC, Pontes JM, Rosa A, Gomes L, Carvalheiro M, et al. (2003) Screening for pancreatic exocrine insufficiency in patients with diabetes mellitus. $A m J$ Gastroenterol 98: 2672-2675. [Crossref]

30. Yilmaztepe A, Ulukaya E, Ersoy C, Yilmaz M, Tokullugil HA (2005) Investigation of fecal pancreatic elastase-1 levels in type 2 diabetic patients. Turk J Gastroenterol 16: 75-80. [Crossref]

31. Ewald N, Hardt PD (2013) Diagnosis and treatment of diabetes mellitus in chronic pancreatitis. World J Gastroenterol 19: 7276-7281. [Crossref]

32. Foulis AK, Stewart JA (1984) The pancreas in recent-onset type 1 (insulindependent) diabetes mellitus: insulin content of islets, insulitis and associated changes in the exocrine acinar tissue. Diabetologia 26: 456-61.

33. Löhr M, Klöppel G (1987) Residual insulin positivity and pancreatic atrophy in relation to duration of chronic type 1 (insulin-dependent) diabetes mellitus and microangiopathy. Diabetologia 30: 757-62.

34. Dyck WP, Rudick J, Hoexter B, Janowitz HD (1969) Influence of glucagon on pancreatic exocrine secretion. Gastroenterology 56: 531-537. [Crossref]

35. Ertan A, Arimura A, Akdamar K, Shibata T, Groot K, et al. (1984) Pancreatic immunoreactive somatostatin and diabetes mellitus. Dig Dis Sci 29: 625-630. [Crossref]

36. Nakanishi K, Kobayashi T, Miyashita H, Okubo M, Sugimoto T, et al. (1993) Relationships among residual beta cells, exocrine pancreas, and islet cell antibodies in insulin-dependent diabetes mellitus. Metabolism 42: 196-203.

37. Terzin V, Várkonyi T, Szabolcs A, Lengyel C, Takács T, et al. (2014) Prevalence of exocrine pancreatic insufficiency in type 2 diabetes mellitus with poor glycemic control. Pancreatology 14: 356-60.

38. Bytzer P, Talley NJ, Leemon M, Young LJ, Jones MP, et al. (2001) Prevalence of gastrointestinal symptoms associated with diabetes mellitus: a population-based survey of 15,000 adults. Arch Intern Med 161: 1989-96.

39. Korc M, Owerbach D, Quinto C, Rutter WJ (1981) Pancreatic islet-acinar cell interaction: amylase messenger RNA levels ar determined by insulin. Science 213: 351-353. [Crossref]

40. Layer P, Zinsmeister AR, DiMagno EP (1986) Effects of decreasing intraluminal amylase activity on starch digestion and postprandial gastrointestinal function in humans. Gastroenterology 91: 41-48.

41. Cigerli O, Parildar H, Unal AD, Tarcin O, Erdal R, et al. (2013) Vitamin D deficiency is a problem for adult out-patients? A university hospital sample in Istanbul, Turkey. Public Health Nutr 16: 1306-1313. [Crossref]

\section{Citation:}

Kadir Demir, Cetin Karaca, Emel Ahishali, Metban Mastanzade, Selda Celik, Nurdan Gul, Fulya Turker, Filiz Akyuz, Fatih Besisik, and Kubilay Karsidag (2017) A Cross Sectional Study to Assess the Prevalence of Pancreatic Exocrine Insufficiency among Diabetes Mellitus Patients in Turkey. Endocrinol Diabetes Metab $J$ Volume 1(4): 1-7 